\title{
NATIONAL ADAPTATION PLANS: A RESPONSE TO CLIMATE-INDUCED MIGRATION?
}

\author{
by
}

Emilia Vydelingum

BSc, University of Waterloo, 2016

MEnvSc, University of Toronto, 2017

A Major Research Paper

presented to Ryerson University

in partial fulfillment of the requirements for the degree of

\author{
Master of Arts \\ in the Program of \\ Immigration and Settlement Studies
}

Toronto, Ontario, Canada, 2019

(C) Emilia Vydelingum 2019 


\section{AUTHOR'S DECLARATION FOR ELECTRONIC SUBMISSION OF A MAJOR RESEARCH PAPER (MRP)}

I hereby declare that I am the sole author of this Major Research Paper. This is a true copy of the MRP, including any required final revisions, as accepted by my examiners.

I authorize Ryerson University to lend this MRP to other institutions or individuals for the purpose of scholarly research

I further authorize Ryerson University to reproduce this MRP by photocopying or by other means, in total or in part, at the request of other institutions or individuals for the purpose of scholarly research.

I understand that my MRP may be made electronically available to the public. 
National Adaptation Plans: A Response to Climate-Induced Migration?

\author{
Emilia Vydelingum \\ Master of Arts, 2019 \\ Immigration and Settlement Studies \\ Ryerson University
}

\begin{abstract}
This Major Research Paper examines the National Adaptation Plans of the Republic of the Maldives and Germany to determine if and how climate-induced migration is addressed. The paper examines how the receiving-migrant countries, and producing-migrant countries look at the forecasted issue from two different perspectives: securitization, and resiliency. In addition, this paper acknowledges that ad hoc temporary migration pathways have had success when dealing with environmental migration and determines that a formal change to the Convention Refugee definition is not necessary to address climate-induced migration.
\end{abstract}

Key words:

Climate Change; Climate-induced Migration; Refugees; National Adaptation Plans 


\section{ACKNOWLEDGEMENTS}

I would first like to thank my supervisor, Dr. Christopher Gore, for his invaluable guidance over the course of this research. I would also like to thank, Dr. Myer Siemiatycki, for his thoughtprovoking questions during my oral review.

To my family, thank you for your words of encouragement and support throughout this degree. 


\section{TABLE OF CONTENTS}

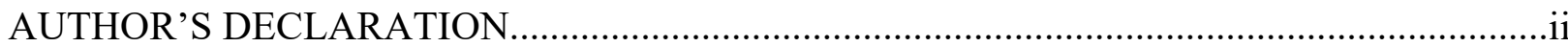

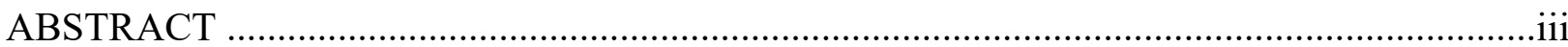

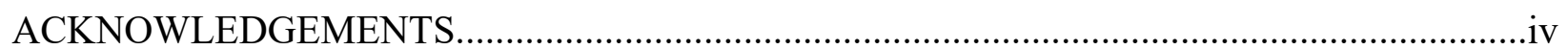

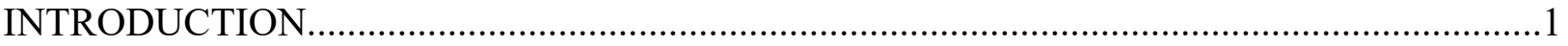

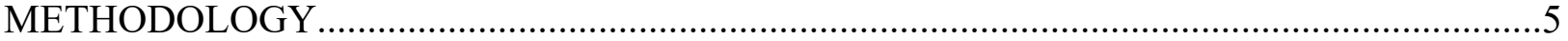

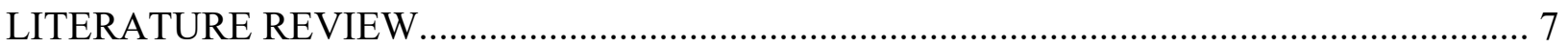

Climate Change and Migration.............................................................................. 7

Climate Change and Vulnerabilities.......................................................................12

Relationship between adaptation, resilience, and migration ............................................14

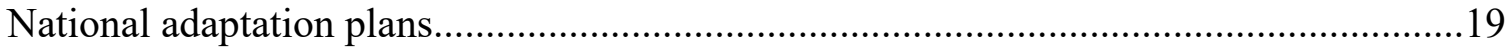

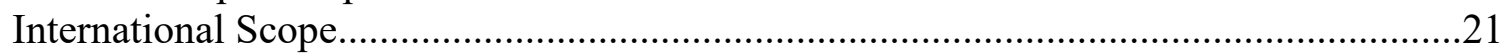

Lack of inclusion of environmental factors in Convention Refugee definition ....22

Human mobility without international climate refugee definition.........................24

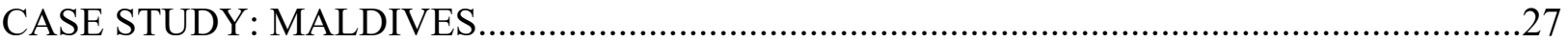

Background on Maldives: Physical and human geography...........................................22

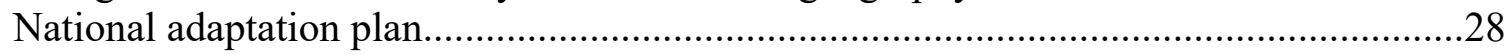

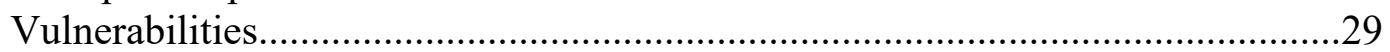

The Maldives and Migration...............................................................................

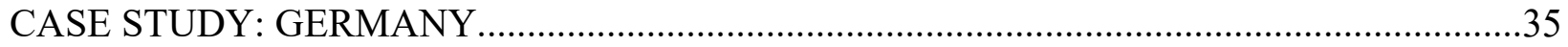

Background on Germany: Physical and human geography..............................................35

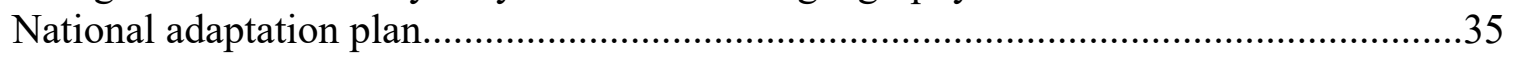

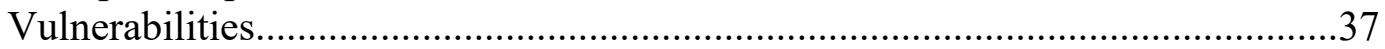

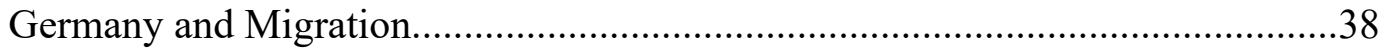

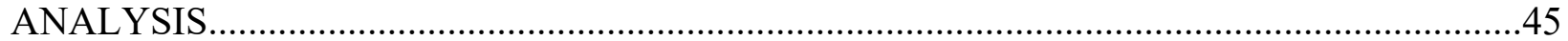

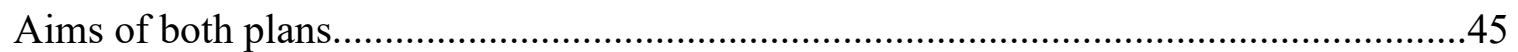

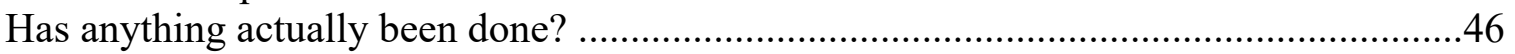

Is there an opportunity to better link displacement and climate in future NAPs?.............47

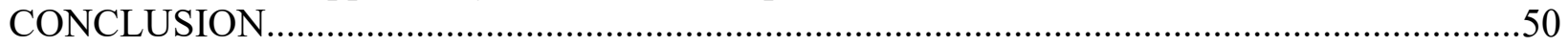

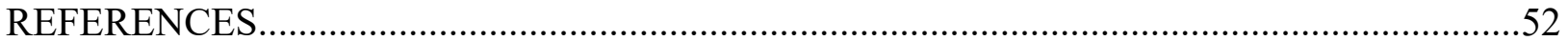




\section{INTRODUCTION}

Climate-induced migration, also referred to as climate change migration or environmental migration, is a socially, politically, and economically complex issue without geographic boundaries (Hamilton et al., 2016). Climate-induced migration is potentially the greatest humanitarian issue caused by anthropogenic climate change (Stapleton et al., 2017).

Anthropogenic is defined by Merriam-Webster (2019) as "resulting from the influence of human beings on nature". This potentially large movement of people can result in both climate migrants and climate refugees (Felli, 2012). The internationally accepted definition of refugee was defined in the 1951 UN Convention as "[...] someone who is unable or unwilling to return to their country of origin owing to a well-founded fear of being persecuted for reasons of race, religion, nationality, membership of a particular social group, or political opinion" (UNHCR, 2017, 3). Given the omission of environmental factors in this definition, people vulnerable to environmental factors (ie., environmental/climate refugees) are without international, legal, and political mechanisms to facilitate and support external mobility. In the absence of consistent formal recognition, the alternative approach is ad hoc and temporary recognition of forced environmental migration. The outcome is that nation-states create policies on a case by case basis that recognize climate events as increasing the vulnerabilities of their population and as causes of migration (Omeziri \& Gore, 2014; Eisenack \& Stecker, 2012). In the absence of international and national legal recognition of environmental factors shaping migration, alternative policies may serve. One example of an alternative are national climate adaptation plans. National climate adaptation plans can recognize internal human displacement and facilitate discourse at international levels to address vulnerable populations. National climate adaptation plans aim to increase the adaptive capacity (i.e., potential for adaptation) of the nation 
state and the methods in these plans can lead to decreases in the vulnerabilities of the population, by for example, promoting or funding mechanisms to reduce coastal erosion (Eisenack \& Stecker, 2012).

Climate events can be addressed by national policies that focus on risk reduction, adaptation, and vulnerable populations (IOM, 2008). Migration is not the primary adaptation response favoured by vulnerable countries, however, it may be the only adaptive response available to countries at greatest risk of inundation (IOM, 2008). As climate-induced migration is multi-causal, an individual's decision to migrate is not determined by climate change alone, but is an action taken by an individual as an adaptive measure (Baldwin \& Fornale, 2017). Largescale displacement or forced migration caused by environmental factors, such as hurricanes or earthquakes, are recognized as migration drivers and often garner large-scale international humanitarian efforts (IOM, 2009). These sudden onset events are best recognized internationally due to their potentially catastrophic consequences, in comparison to slow onset events - such as droughts, that are gradual (IOM, 2009). Gradual onset events create a biophysical environment in which livelihood conditions are constantly undermined and recovery is never completely possible (OCHA, 2011). These gradual onset events slowly diminish the resiliency of a community and their environment to the point of requiring humanitarian aid (OCHA, 2011). If mitigation or adaptation actions - whether by the state or humanitarian actors - are undertaken when a gradual onset event is beginning to unfold, it is possible to reduce and potentially prevent future vulnerabilities (OCHA, 2011).

At the national level, an adaptation plan should address the known slow onset climate events and the adaptation required to offset these events within the country's borders. Increasingly, adaptation plans are transitioning from raising awareness to constructing strategic 
plans to address external environmental events that will impact the nation state (Mimura et al., 2014). As such, national adaptation plans are an alternative way to address human displacement from anthropogenic climate change. Additionally, countries can circumvent the international definition of refugee by creating migration policies at the national level, facilitating human mobility.

Human mobility "refers to all aspects of the movement of people $[\ldots]$ involuntary internal and cross-border displacement of populations, voluntary internal and cross-border migration and planned and consented relocation" (Advisory Group on Climate Change and Human Mobility, 2015). Human mobility policies can be created for internal movement and resettlement as seen in humanitarian visas for natural disaster displacement, and further developed within nation-state climate change policies (Yamamoto, Serraglio, CavedonCapdeville, 2018). At the national level, the state can recognize potential causes for internal displacement and create policies that mitigate these impacts. This paper aims to examine the relationship between adaptation, resilience, and migration through the national adaptation plans of two countries: the Maldives and Germany.

The Republic of Maldives is a Small Island Developing State (SIDS), and Germany is a developed country, both of which have created strategic national adaptation plans. The National Adaptation Program of Action (NAPA) submitted by the Republic of Maldives in 2006 to the United Nations Framework Convention on Climate Change [UNFCCC] and the German Strategy for Adaptation to Climate Change, adopted in 2008, were created to adapt to anthropogenic climate change challenges (RM, 2006; GFG, 2013). Maldives was chosen as a subject of study because of its status as a SIDS and the projected future forced relocation of its population. By contrast, Germany was chosen for its current complex migration situation and its status as a 
developed nation. Both nation-states have put forward national adaptation plans to deal with climatic events and additional stresses to their respective national systems.

The purpose of this research is to ascertain if the national adaptation plans for the Maldives and Germany recognize the relationship between climate events and migration. Recognition on a national scale could facilitate discussions on international platforms as cooperation is required to address climate-induced migration. Given the inability or unwillingness of states and the international community to formally recognize climate displacement as a cause of migration and refugee status, national adaptation plans could serve as a means to recognize and address climate migration at local and regional levels.

The paper will examine the actions presented in the national adaptation plans of Germany and the Maldives to determine if they discuss the adaptive capacity of vulnerable regions and if they present plans that may prevent vulnerable people from becoming climate refugees (McLeman, 2008). Additionally, this paper will determine if the national adaptation plans acknowledge displacement due to climate change and whether they propose actions to address any displacement. Hence, the central questions of this paper is: Do Germany and the Maldives acknowledge displacement in their NAPs? If yes, how? And, finally, is there an opportunity to better link displacement and climate change in future NAPs?

This paper continues with a literature review, then briefly discusses its approach to studying migration and national adaptation plans. It then continues by discussing the cases of the Republic of the Maldives' national adaptation plan, and then Germany's national adaptation plan. It ends with a conclusion. 


\section{METHODOLOGY}

This research paper presents national adaptation plans from a developed country, Germany, and a developing country, the Republic of the Maldives, and examines how each nation state addresses climate-change migrants. The lack of current international legal recognition of environmental impacts under the convention refugee definition is explored from a national-level. In order to provide context to the case studies of the Republic of the Maldives and Germany, a review of literature was conducted focusing on climate-induced migration and domestic mechanisms that address national recognition. Additionally, the literature review identified key terms and concepts within the climate-induced migration field, such as resilience, adaptation, and cooperative agreements. In the following sections, Germany and the Republic of Maldives are used as case studies to ground this research. After the overview of both nation states and their respective adaptation plans, an analysis of whether the national adaptation plans acknowledge climate-induced migration and if it can shape international recognition will be completed. Various developed countries currently apply temporary status measures to address relocation for environmental reasons. Of particular interest is if Germany has considered this mechanism in their national adaptation plan.

Germany and the Republic of Maldives were chosen as the focused case studies. By using purposive sampling, a comparison between developed and developing countries perspectives, impacts, and preparations for forecasted anthropogenic climate change is presented (Creswell, 2013). Germany is representative of developed countries that maintain an advantageous position, in the way, that they are forecasted to be minimally impacted by climate change and they have economic, social, political, and infrastructure in place to increase their adaptive capacity. However, Germany is unique in its geographic position where surrounding 
European nations will be affected by migration but maintain strict immigration policies whereas Germany is the most liberal in its approach towards irregular migrants. To compare and contrast developed and developing countries, the Republic of Maldives was chosen due to its status as a SIDS and its creation of a national adaptation plan. In general, SIDS are forecasted to be the most severely impacted and thus acknowledgement of their populations vulnerabilities and actions taken by their government to increase adaptive capacities within their borders. While this paper compares the Maldives and Germany's national adaptation plan, it is important to acknowledge the current infrastructure as well as their geopolitical position.

This research is focused on two case studies to provide the necessary comparison between national adaptation plans. A case study approach was taken due to the flexibility permitted and that this research involves national plans that are available online (Creswell, 2013). The literature reviewed includes peer-reviewed journal articles, government and nongovernmental organization publications, books, and websites concerning climate-induced migration and its core concepts. As the case study approach is primarily an analysis and interpretation of both countries' national adaptation plans, this research focuses on migration from two different perspectives: national security for Germany and resilience in the case of the Republic of Maldives. 


\section{LITERATURE REVIEW}

\section{Climate Change and Migration}

The relationship between forced migration and environmental factors is often cited within literature to describe the relationship between climate change and migration (Perch-Neilsen et al., 2008). Research on forced migration due to environmental factors was first formalized as an issue with the definition of 'environmental refugee' by El-Hinnawi in 1985, with researchers subsequently categorizing, classifying, and attempting to narrow the concept (Bates, 2002). Drawing on El-Hinnawi's definition, Bates (2002) classified 'environmental refugee' by whether the migrant had agency - whether they were willingly moving or involuntarily moving. Based on Bates (2002) classification, those individuals who are moving involuntarily as a result of an environmental impact are environmental refugees and if the individual is compelled, they become an environmental emigrant (Bates, 2002). The distinctions, as made by Bates (2002), become essential when attempting to create policies to recognize climate-induced migration. Additional distinctions must address short-term or long-term movements, internal or external migration, and documented or undocumented movements of individuals (Till et al., 2016).

Despite the fact that the definition of 'environmental refugee' is still contested, and states and the international community are not using the term as a legal concept, there have been instances of states using temporary special mechanisms to facilitate in-migration as a result of single, large, environmental disasters (Omeziri and Gore, 2014). These special measures are 'wait and see' national policy approaches that do not plan for or facilitate migration as a result of slow-onset environmental disasters (Omeziri and Gore, 2014). Additionally, the uneven distribution of climate change impacts is forcing some nation-states, specifically SIDS, to become frontline advocates to address climate change policies and climate-induced migration 
discussions. By contrast, developed nations can take a backseat to climate-induced migration policy development if they rely on temporary measures only focused on acute environmental events that displace populations (Thomas and Benjamin, 2018; Omeziri and Gore, 2014).

The link between climate change and migration is well researched. The literature outlines that climate change causes environmental degradation and more severe natural disasters, which exacerbate "current vulnerabilities that make it difficult for people to survive where they are" (IOM, 2009, 14). There is no clear causal link between climate change and migration, but rather a non-linear process where anthropogenic climate change affects the environment causing environmental changes, and these changes in turn are a mechanism for migration (Nesheim, 2009). Some researchers consider the effects of environmental factors to be complexly interwoven with social, physical, and economic variables, and any resulting migration can be recognized as a failure in adaptation and development (Homer-Dixon, 1999; Tacoli, 2009; Warrick, 2011). Adaptation can be addressed at international, national, and sub-national levels to capitalize on the adaptive capacity in a particular geographical location (Waldinger, 2015). Currently, countries attempt to address climate vulnerabilities within their borders through adaptation techniques and by creating policy mechanisms, such as national adaptation plans, to attempt to increase the resilience of their populations (IOM, 2008).

Climate-induced migration is a growing area of research in migration studies with diverging views on the responsibility of a government towards their people (i.e., security) and towards environmental refugees. Mayer (2012) discusses the notion of environmental refugee and its lack of international recognition, which results in a lack of policy development. Some scholars, such as Kumar (2014), view large flows of migrants as security risks, and outline specific risks, such as border security, associated with climate-induced migration. In the context 
of national security, the security of the people is the responsibility of the government (Kumar, 2014). Methmann and Oels (2015) approach climate-induced migration from a national level with a 'resiliency as governmentality' perspective. Resilience is defined as "the ability of a social or ecological system to 'absorb changes [...] and still persist'” (Methmann and Oels, 2015, 54). This perspective is where governments should apply resilience in a process that deals with adaptation and insecurity in order to protect the population (Methmann and Oels, 2015, 53). In advanced liberal governments, state policy in response to current climate change impacts places onus on the individual to "either avoid dangerous activities or be willing to pay for appropriate insurance against possible damages" (Methmann and Oels, 2015, 53). This security risk perspective allows for governing from a distance as policies leave the individual with the responsibility to secure their own resilience (Methmann and Oels, 2015). Contrasted by Kumar's (2014) proposal for greater governmental intervention when addressing climate migrants as security risks.

The United Nations and international policy makers view migration as a long-term impact of anthropogenic climate change (IOM, 2009; Stapleton et al., 2017). Anthropogenic climate change will impact all aspects of the biophysical environment and despite the locationspecific nature of climate change impacts, there will be a wide range of global effects such as ocean acidification, drought, water stress, flooding, storm surges, melting of glaciers, increased temperatures that increase vector-borne diseases, and wildfires, etc. (McNutt, 2013; Stapleton et al., 2017). These biophysical changes will alter all physical and social sectors and range in their severity within our global community (Castles, 2013; Locke, 2009).

Researchers acknowledge climate-induced migration as interdisciplinary, straddling social sciences, physical sciences, policy and law disciplines, as well as, becoming increasingly 
politicized (Felgentreff and Pott, 2016). The interdisciplinary nature of anthropogenic climate change and migration creates a plethora of policy perspectives from which to consider economic and political stability, as well as social development factors (Boano et al., 2008; O'Brien and Leichenko, 2000; Felgentreff and Pott, 2016). According to O'Brien and Leichenko (2000), the conceptualization of climate-induced migration must be discussed with economic globalization as well as in direct association to countries that can be 'winners' or 'losers' when facing anthropogenic climate change impacts (223). As climate change impacts are unevenly distributed globally, a winner refers to any country that has a net benefit from climate change impacts, while a loser refers to any country where there are more resultant adverse effects (O'Brien and Leichenko, 2000). This creates a dependent relationship for nation states that are vulnerable to climate change impacts, such as SIDs, where developed countries - many of whom will be largely unaffected - become a sanctuary destination for climate vulnerable countries outmigrants (Locke, 2009). The perspective on migration for developed countries tends to focus on the risks to national security and the securitization of the country rather than developing climateinduced migration policy (Soderblom, 2008). From a developed nation securitization perspective, the risks of accepting climate-induced migrants has the potential to create multitiered security threats (Locke, 2009; Soderblom, 2008). Climate-induced migration researchers address security in two ways: the security of states (national and international) and human security, or people (Huntjens and Nachbar, 2015). While some research has warned of future increases in securitization as a response to climate-induced migration, Huntjens and Nachbar (2015) point out that strategic documents wherein climate change and state security are linked also "emphasized the need for disaster preparedness and measures aimed at building resilience in countries at risk of climate-induced conflict" (4). Disaster preparedness and building resilience 
are some of the main focuses of national adaptation plans, as are adaptation and mitigation techniques that can eliminate vulnerabilities of people (Eisenack and Stecker, 2011). According to Trombetta (2014), addressing climate-induced migration at an international level will only occur once nation states who are accepting climate migrants engage in a transformation of national security practices: from threat-based to monitor-based. For developed countries, national adaptation plans consider threat-based practices over monitor-based practices as that is traditionally how they address external security concerns. From an environmental migration perspective, environmental migrants should not be considered as external security concerns but rather as an international security concern, with developed nations being a part of the greater community.

Other climate-induced migration research points to a predicted shift in the primary cause of forced migration, from a persecution paradigm to an economic paradigm (McMichael, 2013). According to McMichael (2013), the global scale of interconnectedness between contemporary economic and human activities, and the degradation of the environment is historically unprecedented. This perturbs personal security (ie., access to food, water, sanitation, and shelter), and can drive the movement of people (McMichael, 2013). According to Castles (2013) and McMichael (2013), the capitalist, neoliberal, globalized system creates forced transnational exploitation that will have continued and prolonged biophysical consequences, specifically as underdeveloped countries are forced to adapt to the impacts of climate change. Since underdeveloped countries do not hold the power to enact the changes required to mitigate climate change, the unequal global division of decision-making power creates a hierarchy through which developing countries must submit to the established neoliberal globalized system (Castles, 2013; O’Brien and Leichenko, 2000; Felgentreff and Pott, 2016). This creates a barrier for 
disadvantaged and vulnerable nation states, such as SIDS, in preventing catastrophic situations within their borders as these impacts are dependent on developed, and emerging (ie., Brazil, India, China) country policies.

\section{Climate Change and Vulnerabilities}

In the context of climate-induced migration, the term vulnerability refers to geophysical, biological, and socio-economic systems becoming unable to cope with the adverse impacts of climate change (IPCC, 2007a; Vincent, 2004). These climate-sensitive systems' inability to cope with adverse anthropogenic climate change impacts will have repercussions in social, security, economic, and environmental sectors through the creation of new vulnerabilities and the increase in any existing vulnerabilities (IPCC, 2007; IPCC 2007a; Vincent, 2004). Vulnerability is defined by the UNFCCC as

"The degree to which a system is susceptible to, or unable to cope with, adverse effects of climate change, including climate variability and extremes. Vulnerability is a function of the character, magnitude and rate of climate variation to which a system is exposed, its sensitivity and its adaptive capacity. Therefore, adaptation would also include any efforts to address these components (UNFCCC, 2018)"

For many countries, pre-existing vulnerabilities are a result of uneven economic development, poverty, natural disasters, and precarious livelihood systems (Felgentreff and Pott, 2016). These factors can contribute to increasing their populations' likelihood for forced displacement (Felgentreff and Pott, 2016). Country specific vulnerabilities can be addressed through adaptation or mitigation, or a combination of both, however, these options are limited to nations with the socio-technical and structural arrangements, including a stable government, to create actionable national plans (Felgentreff and Pott, 2016). Many developing countries create plans but are dependent on their government's access to technological, and economic resources - 
and more often than not, international aid - to implement these policy changes (Eisenack and Stecker, 2011). In contrast, developed countries have more resources available to them to reduce the vulnerabilities of the population by creating legislation that builds the overall resilience of the country. Unfortunately, no policies have been created as most developed countries do not address migration as a plan to deal with vulnerability to climate change (European Parliament, 2011). The inability to access resources reinforces nation-state vulnerability and can ensure that forced migration is the only solution to environmental changes.

From an international economic perspective, developing nations are more vulnerable to climate change impacts as their economies are primarily climate-reliant activities, such as farming and fishing (Wijaya, 2014, 2). According to Locke (2009), the lack of financial and logistical capacity for developing nations to face rapidly changing climatic conditions will cause them to employ traditional migration adaptation strategies to environmental hazards (172). A 'traditional' migration adaptation strategy reflects the inability for those individuals impacted to do anything but migrate away from the area affected (Locke, 2009). This issue stems from the lack of capacity of nation states to respond adequately, particularly in logistical capacity.

Logistical capacity is defined by the International Organization of Migration [IOM] as building the capacity of governments and civil society by increasing their knowledge and enhancing their skills. Capacity building can take the form of substantive direct project design and implementation with a partner organization, training opportunities, or in other circumstances facilitation of a bilateral or multilateral agenda for dialogue development put in place by concerned authorities. In all cases, capacity building aims to build towards generally acceptable benchmarks of management practices. (IOM, 2011).

Locke (2009) furthers the dialogue that developing nations are unable to meet the forecasted displacements by examining their current existing logistical capacity and governmental infrastructure. The existing logistical capacity and governmental infrastructures within developing nations are functioning at below minimum threshold capacity (Locke, 2009). 
Threshold capacity are "factors contributing to the line demarcating the tolerability of a place from inhabitability" (IOM, 2016). If countries are functioning at below threshold capacity, it means water, food, shelter, and strong government institution are not robust enough to withstand drastic changes, like a natural disaster, without throwing the entire system into chaos (IOM, 2016). To build on this concept, Nightingale (2017) states that "biophysical change combined with marginalisation creates vulnerability to climate change, and [...] the best way to adapt is through a variety of technical and institution building measures" (11). In order to build infrastructure, adaptation programs are designed to capitalise on the changing biophysical resources and to cope with adverse climate impacts within the region (Nightingale, 2017). However, in order to build an adaptation plan, national and even regional governments must identify specific hazards that lead to vulnerabilities and those must be addressed (Nightingale, 2017). Building national adaptation plans can also address national and human security, as well as the natural hazards within the nation-state's borders.

\section{Relationship between adaptation, resilience, and migration}

In the context of climate-induced migration, researchers often address adaptation, resilience, and migration together; however, the relationship between these three elements depends on the policy perspective (i.e., the focus of the policy), and the scope of the research (Scheffran et al., 2012). The link between adaptation, resilience, and migration is indirect as the relationship depends on the extent, duration, and preparedness of the nation state in advance of the environmental hazard (Methmann and Oels, 2015). While international mechanisms, such as those embodied in the United Nations and partner organizations, are available as resources to 
create actionable national adaptation plans, political instability and low economic status of a country weakens the potential success of a plan (Nightingale, 2017).

The resiliency approach to climate-induced migration is a 'migration-as-adaptation' response (Baldwin and Fornale, 2017). Tied to this, is the acceptance of anthropogenic climate change as real and the impacts of anthropogenic climate change on the nation-state. By addressing and accepting the impacts of anthropogenic climate change, there is responsibility placed on developed countries to mitigate their greenhouse gas emissions in an attempt to prevent catastrophic and slow onset disasters, such as sea level rise (Methmann and Oels, 2015). For developing countries - specifically SIDS- the creation of 'migration-as-adaptation' policies acknowledge the future loss of their homes, country, livelihood, and way of life (Roberts and Andrei, 2015). For some SIDS, adaptation can build resilience but may not prevent forced migration as the final adaptation step (Roberts and Andrei, 2015).

Resilience can be explored from a variety of different perspectives. From an economic perspective, Barnett and Webber (2010) detail the benefit of remittances to smaller developing countries. By contrast, Adger et al. (2012) approach climate-induced migration from a cultural perspective, where "the implications of a changing physical environment touch the core of how individuals and cultures may define themselves and their interactions with the world around them" (349). Analysis of national adaptation plans requires attention to the social details (i.e., the distribution of vulnerable populations) included within the technical details of the plan (Adger et al., 2012). Additionally, Watkiss and Cimato (2016) state that a greater focus on adaptation is increasingly important during the scoping phase (the beginning), and in the appraisal (the end) which provides a temporal analysis. Combining Adger et al. (2012) and Watkiss and Cimato (2016), an in-depth analysis can be conducted to determine resilience through examining 
temporal and technical developments within the national adaptation plans. Temporal developments examine changes over time that can increase resilience, while technical developments are any technology that enhances community resilience (Watkiss and Cimato, 2016). While the economy plays a large role in the development of climate migration policies, geopolitics and developmental aid also exert significant influence on policy development. Nightingale (2017) addresses the significance of geopolitics within development aid and the role of geopolitics in shaping national efforts for adaptation. Adaptation plans usually employ cooperative arrangements aimed at creating successful management structures (Nightingale, 2017; Muradin and Rival, 2012). Cooperative arrangements can occur between countries that have other agreements, for example, the European Union, and often times, development is funded by international organizations that are formed within these cooperative arrangements (Nightingale, 2017). Management structures are considered successful when they encompass institutions that can govern the relationship of environmental, and social resources (Nightingale, 2017; Muradin and Rival, 2012). For example, successful water management results in the ability of a country to meet "the ever-increasing demands from demographics, economic and climatic pressures" (UN Water, 2014). Within the context of development aid, the realities of the geopolitical role of developmental aid are manifest in the improved reputation of the donating country on an international platform and that the donating country can develop access or control over the natural resources in the receiving country (Nightingale, 2017; Girvan, 2007). While this is one view, there are often less self-interested views where developmental aid goes towards human rights, water quality, waste management and other aspects to improve living conditions and target social areas needing attention. If the country receiving aid does not have a sound political system, their system can be influenced by the development aid being received and that 
can impact their ability to increase resilience (Nightingale, 2017; Girvan, 2007). However, within the context of adaptation as resilience, developmental aid provides the necessary resources like policy creation and access to resources that developing countries have difficulty accessing and funding (Watkiss and Cimato, 2016). Watkiss and Cimato (2016) emphasize that adaptation is a process that can be applied to long-term acting policies. Mainstreaming, as applied by Watkiss and Cimato (2016) is defined as "the integration of adaptation into existing policies and decision-making, rather than implementation of standalone adaptation policies, plans, or measures" (2). Mainstreaming adaptation into national adaptation plans could create the policies required to address climate migrants effectively.

Migration is increasingly considered to be an adaptation strategy to climate change. According to Waldinger and Fankhauser (2015), "planned, proactive migration may be a necessary and effective response to climate risks [...where] uncoordinated distress migration is a sign of adaptation failure" (7). Adaptation policies that ensure effective and coordinated migration as a solution should include information such as cost-benefit analysis, changes to institutions, legal status changes, and safeguards to prevent improper adaptation strategies (Waldinger and Fankhauser, 2015). Internal migration occurs when people residing within the country migrate away from their home but remain within their country's borders. Conversely, external migration occurs when people migrate to outside their country. For countries to address sub-national environmental impacts, creating migration policies facilitating internal movement is considered a method of adapting to climate change (Waldinger and Fankhauser, 2015). Migration as adaptation can be either internal or external, with successful policy development to address both cases. 
Internal and local migration is suggested by researchers as the preferred type of migration by migrants resulting from environmental condition changes (Piguet, 2010). Internal migration is defined by Skeldon (2017) as "migrants [who] move within the boundaries of their own country" (4). This includes internal migrants who transition between urban and rural settings (Skeldon, 2017). Raleigh et al., (2008) add that "internal migration is one such coping strategy [used by migrants for environmental impacts] and is a frequent response to both economic and environmental hardship" (2). Internal migration is considerably easier as human and social networks, political and financial capital, and status of the migrant is not necessarily affected. With external migration, migrants may be affected by barriers, such as language, financial capital, and education (Newland, 2011). External migration barriers can also be faced by migrants who migrate internally, and these barriers are strongly dependent on the geopolitical and societal structures within the country.

Currently, external or international migration is primarily driven by economic, social, and environmental reasons and by those fleeing conflict (United Nations, 2017). In many countries, immigration policies have different streams addressing economic, family class, and refugee streams, wherein those applying through the economic stream face less restrictions and increased opportunities to be accepted (Winter-Ebmer, 1994). Tied to this stream is the agency of the migrant in his or her choice to migrate, which also holds true for family class (Mainwaring, 2016). In contrast, refugees must meet the convention refugee definition prior to being granted asylum and can be refused if taking a clandestine route (Mainwaring, 2016). For those vulnerable to anthropogenic climate change, clandestine routes could become the main method of international migration causing increases in human smuggling and furthering the vulnerability of those utilizing those methods (Mainwaring, 2016). 
According to a report released by the United Nations (2017), most migration tends to be regional migration. Verhelst (2017) proposes that bilateral arrangements, imposed at a national level, as a solution to climate-induced migration by stating that the arrangements "can be tailored to the historical and political connections between the home and receiving states" (37). In this way, external migration is facilitated through context-specific mechanisms that do not require the convention refugee designation (Verhelst, 2017). The United Nations (2017) has also highlighted that bilateral corridors (defined as "migratory movements between pairs of countries" (14)) have been successful to address population declines in some areas and this mechanism can use nonbinding instruments while maintaining migrant movement (Verhelst, 2017). These bilateral corridors can be used within national adaptation plans as some agreements between countries already exist.

\section{National adaptation plans}

National adaptation plans (NAP) are methods of identifying "long-term adaptation needs and developing and implementing strategies and programmes to address those needs" (UNFCCC1, 2018). Supported by the United Nations, national adaptation plans are developed by every nation state to address national climate change impacts, and methods to adapt or mitigate forecasted area-specific climate change impacts (UNFCCC1, 2018). The United Nations NAP guidelines for least developed countries [LDCs] include addressing the groundwork, preparatory

elements, implementing strategies, and reporting and monitoring (UNFCCC, 2011). These plans are for the nation state to prepare for climate change impacts and build adaptive capacity by creating climate resilience (UNFCCC1, 2018). The guiding principles are as follows:

(1) "Be undertaken in accordance with the Convention; 
(2) Follow a country-driven, gender-sensitive, participatory and fully transparent approach, taking into considerations vulnerable groups, communities and ecosystems;

(3) Be based on and guided by the best available science and, as appropriate, traditional and indigenous knowledge, and by-gender-sensitive approaches, with a view to integrating adaptation into relevant social, economic and environmental policies and actions, where appropriate;

(4) Not be prescriptive, nor result in the duplication of efforts undertaken in-country, but facilitate country-owned, country-driven action" (UNFCCC2, 2018).

Several nation-states have released national adaptation plans and have goal-driven targets (UNFCCC2, 2018).

National adaptation plans generally include "a better way of doing business, of fully considering climate change concerns in planning and decision-making processes" (LCD Expert Group, 2012, 14). The process includes 4 main elements that can be undertaken at different times by different countries. The main elements are to lay the groundwork and address gaps; develop preparatory elements; implement strategies; and report, monitor and review the plans (LCD Expert Group, 2012). Each country has different capacities and the UN states that countries have the discretion to develop and move from each element in their own time (LCD Expert Group, 2012). There are technical guidelines for the NAP process, but there are limited studies to show if the plans developed have been implemented successfully. According to Biesbroek et al. (2010), national adaptation plans are "a new political commitment to adaptation at national policy levels" (440). However, they note that there are minimal approaches to implement and evaluate the plans in place (Biesbroek et al., 2010). As evaluation of the plans by the United Nations have not yet been done, it is difficult to comment on the effectiveness and the strength of the plans already developed (Biesbroek et al., 2010).

Roles and responsibilities in the NAPs vary between developing and developed countries. Developing countries are to report on any steps they have taken as part of their NAP process as 
well as on any support received in the process (Manasfi and Sepp, 2013). Developed countries are to "provide developing countries with technical support, including capacity development and the identification of adaptation measures" (Manasfi and Sepp, 2013). The development of national adaptation plans occurs as countries have acknowledged climate change as a problem and have agreed that a collective response is required to address it. While the roles between the countries vary, they pursue the same goal: increasing their national resilience to climate change (Manasfi and Sepp, 2013). National adaptation plans consider sub-national impacts as well as global impacts. This consideration causes national adaptation plans to address global impacts while still focusing on their own country.

\section{International Scope}

Anthropogenic climate change will affect all areas of the globe producing social, political, economic, and physical challenges. These challenges will disproportionately affect developing countries. The definition of a convention refugee is "[...] someone who is unable or unwilling to return to their country of origin owing to a well-founded fear of being persecuted for reasons of race, religion, nationality, membership of a particular social group, or political opinion" (UNHCR, 2017, 3). With the lack of inclusion of environmental factors under the convention refugee definition, there are limited legal options for those migrants who will be required to flee their environment. Some researchers call for the inclusion of 'environmental factors' under the convention refugee definition which presents an international scope to which nation-states would have to agree and ratify a new definition of convention refugee (Bruno et al., 2017; Compton, 2014; Waldinger and Fankhauser, 2015). Other researchers state that migration will happen with or without international recognition and that the benefit of creating international legislation is that there will be less risk to the migrants as those facing 
environmental migration will not be forced to take more dangerous and clandestine routes (Mainwaring, 2016; Waldinger and Fankhauser, 2015).

\section{Lack of inclusion of environmental factors in Convention Refugee definition}

For those individuals vulnerable to climate change impacts, the lack of international recognition of environmental factors under the definition of refugee release ratifying nationstates from responsibility towards climate-vulnerable individuals (IOM, 2011). The International Organization for Migration (IOM) has recognized that "the definitions in this field are often vague, controversial or contradictory" (IOM, 2011, 5). Many broadly defined or undefined migration terms can be interpreted in different ways by various bodies, such as governmental agencies, and NGOs (IOM, 2011). The variance within migration terms can be at a regional, national, or international level (IOM, 2011). The IOM states that "where there are no universally accepted definitions, the potential exists for each group to decide, formally or informally, on its own definition, according to its perspectives" $(2011,5)$. This ambiguity or lack of firm definition does not hold true for the definition of refugee.

The term refugee, as defined in the 1952 UN Convention, focuses on socio-political persecution without covering environmental impacts (UNHCR, 2017). It is important to acknowledge that the creation of the refugee rights in international law was as a response to the atrocities and persecution of World War II. Today, the global community is facing a different threat - climate change - and to avoid atrocities, pre-emptive measures to control, adapt, and mitigate potentially catastrophic impacts must be taken. According to Compton (2014), reforming the definition of refugee could provide the solution required to offer "adequate protection [to] the growing and diversified classes of refugees in our international system" (380). 
Compton (2014) suggests expanding or removing "because of past persecution or a well-founded fear of future persecution," and "on account of race, religion, nationality, membership in a particular group, or political opinion" (381). An alternative approach for inclusion of environmental refugees within the 1951 Convention refugee definition is presented by Rempell (2013) who calls for the expansion of the term persecution (284). According to Rempell (2013), there is hesitation by immigration agencies and judicial systems because keeping persecution undefined provides flexibility and broadens the term (286). A similar idea is also explored by Maiani (2010) who states that "if the concept of persecution could be expanded or narrowed at will, then the states would be at liberty to re-define the scope of their obligations as they see fit" (1). This can go either way following local and geopolitical shifts. Redefining persecution could either create an international legal protection for environmental refugees or remove the ambiguity resulting in increased vulnerability.

This introduces environmental persecution and presents a dilemma as to how to evaluate if environmental persecution is occurring. According to Ragheboom (2017), while "environmental persecution is not explicitly mentioned in refugee law, $[\ldots]$ " “[n]othing in either international or national standards explicitly disavows the idea that one may be persecuted through environmental harm" (303). Ragheboom (2017) proposes that severity and seriousness of the impact can be used as criteria for evaluation of environmental persecution, as these factors are also considered in the evaluation of persecution when applying the Convention Refugee definition. Ragheboom (2017) states that:

Situations of sudden or slow-onset environmental degradation, in which dwellings and infrastructures are destroyed or threaten to be, resources are reduced or scarce, and State authorities weakened, unquestionably hamper, or possibly prevent, people's enjoyment of their human rights. Environmental disasters affect populations as well as, by nature, their conditions or standard of living. (312) 
Examining persecution from a definitional perspective indicates that environmental factors can indeed be encompassed under the current persecution definition. However, persecution indicates that there is a persecutor and that element remains unclear for environmental persecution. The argument presented by Ragheboom (2017) is one of state accountability, in that, a state should step forward when they can offer protection when and if another state is unable to. While the criteria for environmental persecution has yet to be determined, it is important to note that countries are able to create some of their own factors (i.e., what constitutes an environmental hazard?) to the Convention Refugee definition due to the broad or undefined terms used (Regheboom, 2017). These factors can be determined at a national level and could be proposed or examined within the scope of a national adaptation plan.

\section{Human mobility without international climate refugee definition}

The literature applies adaptation, adaptive capacity, and resilience concepts to climateinduced migration and climate events. The responsibility of developed countries towards climate refugees remains undetermined in international law, but national adaptation plans could address and prepare for climatic events that could relocate their population (Waldinger, 2015; Thomas and Benjamin, 2018; Stapleton et al., 2017). This has the potential to integrate climate-induced migration into adaptation planning and provide national policies and laws for climate migrants and climate refugees (Pierre-Neilson et al, 2008). Additionally, these national policies and laws can fill the void within international law by addressing these migrants (Compton, 2014; Waldinger and Fankhauser, 2015).

Whether or not the term refugee is broadened or altered to accommodate the evolving class of environmental refugees, there will be human mobility without a definitional change (Compton, 2014, 386). Sometimes this mobility is promoted by the receiving countries policies 
through temporary measures that can provide long-term status to the individual (Omeziri \& Gore, 2014). These temporary measures can often present an alternative to a definitional change (Omerizi \& Gore, 2014). The autonomy of migrants is an important factor when determining migration flows, as migrants are actors that choose destinations, durations, and that results in development outcomes of either productive or unproductive migration for the migrant (Waldinger and Fankhauser, 2015). In addition, receiving countries often evaluate based on some notion of productive or unproductive migration (Waldinger and Fankhauser, 2015). According to Mainwaring (2016), migrants will still find migration pathways, however the journey might be riskier than required, with clandestine routes being the only option available. Those migrants who "demonstrate agency, especially those who thwart state controls in order to enter a country, are likely to be securitized and depicted as villains who undermine a nation's security, labour markets, and identity" (Mainwaring, 2016, 290). These decisions affect how countries respond to migration crises and impact the migrants' ability to integrate into society (Waldinger and Fankhauser, 2015; Mainwaring, 2016). In an effort to address migration prompted by adverse climate events, a temporary status for climate change migrants can be pursued in certain developed countries.

In the current geopolitical climate, some nation states such as Canada and the United States use temporary protected status [TPS] to grant status to those fleeing from natural disasters until conditions improve in their country (Hollifield and Salehyan, 2015). TPS grants temporary status depending on the severity of the crisis and provides a work permit to foreign nationals from countries unable to protect their citizens (Compton, 2014). TPS is currently the only method that permits foreign nationals into developed nation states with status, albeit temporary, following natural disasters (Compton, 2014). According to Compton (2014), "TPS is a helpful 
and essential benefit for the short-term, it is not a meaningful solution to the impending global crisis of environmentally displaced migrants (376)." Additionally, when comparing "the number of people in developing countries engaging in internal migration, the number of people engaging in international migration is small" (Waldinger and Fankhauser, 2015, 11). Therefore, national adaptation plans promoting internal adaptation techniques are more likely to be successful if designed, enacted and actioned properly (Watkiss and Cimato, 2016).

National adaptation plans create the opportunity for countries to develop strategies to increase resilience and decrease their vulnerability to climate change. National policies can act as policy mechanisms for environmental migration circumventing the international Convention Refugee definition. For many countries, addressing pre-existing vulnerabilities provides opportunities to build resilience while improving identified infrastructure, environmental, and human system problems. Climate-induced migration is potentially the greatest humanitarian issue caused by anthropogenic climate change and efforts must and are being made to address it (Stapleton et al., 2017). 


\section{CASE STUDY: MALDIVES}

\section{Background on Maldives: Physical and human geography}

The Republic of Maldives is a nation state located in the Indian Ocean composed of 1,190 low-lying islands within 25 coral atolls (Maldives, 2018; RM, 2006). Out of the 1,190 islands, there are only 358 islands that are inhabited (RM, 2006). The maximum height of the islands is approximately 3 meters above sea level, with most only rising about 2 meters above sea level (Khan et al., 2010). Malé, the capital, is the hub of economic and tourist activities (RM, 2006). The Maldives has a population of approximately 436 thousand as of 2017 (Maldives, 2018). For the Republic of Maldives, tourism is a focal point for the economy, as there are picturesque beaches, blue lagoons, and reefs (Holidays and Host, 2018). Tourism is also a cause of environmental impacts. These impacts include pollution of the water and land, clearing land, and lack of infrastructure for disposal of solid waste and sewage (Brown et al., 1997). With the added environmental stress of anthropogenic climate change, the environment will be challenged and ultimately unable to maintain the same tropical ecosystem typically found in this region (RM, 2006).

The Maldives is composed of coral islands that are morphologically unstable. This instability leads to temporal changes in size, shape, elevation and position of the reef leading to seasonal changes in the beaches (MoEEW, 2007). These beaches serve as a settlement area and an increasing area of vulnerability as extreme (i.e., storm surges) and slow onset (i.e., rising sea

level) events threaten the population (MoEEW, 2007). For these reasons and other threats caused by anthropogenic climate change, the Maldives took an active role in the creation of the UNFCCC and "was the first nation to sign and ratify the Kyoto Protocol" (MoEEW, 2007, 1). For the Republic of Maldives, anthropogenic climate change poses threats at a scale that can 
cause the Maldives to become an uninhabitable area (RM, 2006). The impacts of climate change have created the circumstance where a national adaptation plan is required.

\section{National adaptation plan}

The Republic of Maldives submitted a 114-page National adaptation program of action (NAPA) to the United Nations Framework Convention on Climate Change [UNFCC] in 2006. This adaptation plan was prepared by the Maldivian government's Integrated Climate Change Strategy projects of Ministry of Environment, Energy and Water (MoEEW, 2007). The central focus of this plan is "to present a coherent framework to climate change adaption that enhances the resilience of the natural, human, and social systems and ensures their sustainability in the face of predicted climate hazards" (MoEEW, 2007, 3).

The national adaptation plan is centered on the enhancing resilience and ensuring sustainability of the natural, human and social systems in Maldives (MoEEW, 2007). The policy framework uses definitions as presented by the Intergovernmental Panel on Climate Change [IPCC] but also creates a plan-specific definition of adaptation, as follows: "a multi-dimensional goal that aims to increase resilience of the vulnerable systems against climate hazards and risks to achieve sustainable development outcomes" (MoEEW, 2007, 3). The adaptation plan provides context to climate hazards and risks, and addresses adaptation techniques. The document calls attention to the absence of local-level fixes and re-emphasizes the need for the international community to maintain commitments to the Kyoto Protocol (MoEED, 2007). This plan acknowledges that the policy framework is not perfect as knowledge of the complex relationships between societies and ecosystems are not completely understood (MoEEW, 2007). 
Migration is addressed through the discussion of plans to build resilience into infrastructure for possible internal relocation, but does not address discuss plans for external migration.

The adaptation plan has seven chapters: (1) the introduction, (2) the adaptation policy framework, (3) national development, (4) climate change and climate variability, (5) vulnerabilities and impacts, (6) adaptation needs and priority adaptation strategies, as well as (7) adaptation projects (MoEEW, 2007).

\section{Vulnerabilities}

The plan presents a list of the vulnerabilities faced by the community in the natural, human, and produced systems (MoEEW, 2007). The adaptation plan defined the natural system as environmental resources such as renewable natural resources, non-renewable resources, the quality of the ecosystems and services produced, maintenance of biological diversity, and space where human activities occur (MoEEW, 2007). The human system "refers to human lives, human health and knowledge, skills and competences of individual," and the produced systems are "the human-made material resources that can be used to produce a flow of future income which includes basic infrastructure, and production equipment such as machinery and tools" (MoEEW, 2007, 5). Vulnerabilities must be addressed in both the human and produced systems in order to increase resilience.

The natural system will be faced with sea level rise, extreme weather and events, increasing temperature, and changes to precipitation patterns (MoEEW, 2007). Physical impacts include extreme events such as cyclones, storm surges, tropical depressions, heavy rainfalls, floods, and droughts (MoEEW, 2007). From those physical impacts, the produced and human systems are facing potential growth collapse in the tourism, fishery, and agriculture industries as well as facing decreases in the gross domestic product (GDP) (MoEEW, 2007). This can lead to 
financial crises and the inability to balance the national budget. For example, storm surges can destroy some of the Maldives' infrastructure which can cost a lot to repair while simultaneously affecting the tourism industry. Additional hazards with varying temporal impacts that can affect implementation of the national adaptation plan are political instability, natural disasters, social upheaval, civil strife, and terrorism (MoEEW, 2007).

Vulnerability assessments identify that due to the low elevation and unconsolidated coral islands, sea level rise will impact at minimum $44 \%$ of current human settlements as they are within 100 meters of the coastline (MoEEW, 2007, 20). The existing infrastructure is not built to withstand extreme events, such as flooding and swells (MoEWW, 2007). Settlements are vulnerable as housing designs, flooring, and poor construction were not created to withstand minimal flooding (MoEWW, 2007). The Maldives has increased pressures on their social systems as the "population of the country has increased by four-fold since 1911 and overcrowding is a significant problem" (MoEWW, 2007, 21). With increase population size, existing infrastructure is already strained and the strain will only increase with time.

For the Maldives, human activities have increased the vulnerability of the land (MoEWW, 2017). The Maldives has poorly designed coastal infrastructure and coastal protection measures. Additionally, there has been coastal vegetation removal and sand mining which increases the vulnerability of coastal erosion (MoEWW, 2017). Human activities have increased the vulnerability of coral reefs such as "coral mining, reef entrance blasting, dredging, solid waste disposal and sewage disposal that has affected the health, integrity and productivity or reefs" (MoEWW, 2007, 22). While many other nation states have also employed these activities, the scarcity of land has decreased the resilience of the Maldives (MoEWW, 2007). 
The vulnerabilities are addressed through adaptation strategies presented in chapter 6 of the national adaptation plan. An extensive list of the Maldive's adaptation needs included 30 measures, all given a priority score, from the following sectors: land, beach and human settlements, critical infrastructure, tourism, fisheries, human health, water resources, agriculture and food security, and coral reef biodiversity (MoEEW, 2007). The top priority is to "build capacity for coastal protection, coastal zone management and flood control”, followed by "consolidate population and development" (MoEEW, 2007, 43). To address the aforementioned vulnerabilities, 12 projects were designed with all the projects geared towards increasing adaptive capacity through enhancing infrastructure (MoEEW, 2007). The enhancement of infrastructure is one of the main preparations that can be used to promote internal relocation and ease pressures on human and physical systems. This national adaptation plan highlights that the Maldives is in the process of addressing infrastructure vulnerabilities for when internal migration occurs. While internal migration is acknowledged within the national adaptation plan, there is no proposal for moving the population. The projects put forth by the Maldives specifically target coastal protection for the islands as well as the Male airport (MoEEW, 2007, 54). The projects are presented in 2-3 pages and include the rationale, a description, the implementation plan of the proposed project, and the budget. While the priority of the projects is clear, they are all big projects that encompass large, technical infrastructure changes and require large amounts of money. While these changes can improve adaptability, the source of income is not clear. Therefore, the vulnerabilities have been determined as well as the priority level, but the action plan remains unclear as the means to move towards actions are still general and unfunded. 


\section{The Maldives and Migration}

The Maldivian national adaptation plan begins with a powerful quote from President Maumoon Abdul Gayyoom, “...there must be a way out. Neither the Maldives nor any small island nation wants to drown. That's for sure. Neither do we want our lands eroded nor our economies destroyed. Nor do we want to become environmental refugees either. We want to stand up and fight" (MoEEW, 2007, 1). This statement shows that while the Maldivian government aims to address climate hazards and vulnerabilities, it can be implied that migration is the last resort for the population. This is also the only time environmental refugee and the concept of outmigration is mentioned in the entire national adaptation plan. Perhaps this signifies hope that global mitigation proposals are being adhered to and that the national adaptation framework for the Maldives does not need to extend past its own borders. For the Maldives, outmigration mentioned only once in the national adaptation plan expresses a strong stance on independent statehood with a particular focus on internal changes instead of dependency on the willingness of other nation states to provide an area for relocation.

Former president Gayyoom is clear that outmigration is not a policy preference. His quote points to the Maldivian perspective to fight to maintain their way of life, but the unanswered question is how can the Maldives prevent climate change when they are not the main perpetrators of the climate change and what are they fighting? There is a lack of substantive progress in the development of internal and external migration plans at a national level for the Maldives despite the worst-case scenario of anthropogenic climate change for the Maldives being outmigration (MoEEW, 2007). However, the discussions on international platforms regarding the worst-case scenario Maldivian outmigration draw international attention to the environment-migration nexus. This could be due to the politically sensitive nature of 
outmigration as it reinforces a reliance on other nation states. Given the location of the Maldives, Maldives has been and continues to be affected by the global community's action as a whole and they are expected to disproportionately impacted by climate change. The leader of a nation could not predict the fall of their country and suggest to their own people that their home will be gone. Despite this potential reality for the Maldives, a politician and a leader could, but likely will not, present to their people that they will lose their homes.

Former President Maumoon Abdul Gayyoom suggests that the Maldivian people are willing to fight for their land, culture, and nation. While migration discussions on international platforms occur, the Maldives' national perspective does not focus on the loss of land and eventually becoming refugees. The call to action acts to potentially increase income through developing plans for infrastructure, thus improving the current socio-economic situation in the Maldives (MoEEW, 2007). This positive outlook can improve the daily living situation of the Maldivian people.

In addition to the 'stay and fight' mentality, internal migration from outer islands into the islands with higher elevations has been considered (MoEEW, 2007). With this relocation, a higher concentration of people results in a higher concentration of use of resources. The plan states that "there is limited opportunity for communities to retreat inland" (MoEEW, 2007, 66). This requires infrastructure that the Maldives has to adapt and provide prior to the relocation (MoEEW, 2007). Internal migration is recognized and this national adaptation plan presents methods to address societal and environmental pressures due to the relocation (MoEEW, 2007). This indicates that abandoning their country is not an option, but relocation within its borders is a viable solution. 
It is important to acknowledge that it is difficult to create a national adaptation plan for a scenario that has not occurred before. The Maldives will be one of the countries most impacted by climate change, yet, it has not introduced not introduce any migration policies or plans for either internal or external migration. While a call to action attracts international attention, some flags should be raised within the international community, as migration remains largely unaddressed. Additionally, at the time of the national adaptation plan publication, the Former President did not tell people that they will lose their homes as the international voices were hopeful for international cooperation in decreasing greenhouse gas emissions. Also, a national adaptation plan looks at how to address and decrease vulnerabilities, as such, it could prove difficult to create a plan detailing a loss that substantial for public consumption. 


\section{CASE STUDY: GERMANY}

\section{Background: Physical and human geography}

Germany, located in central Europe, has a temperate and marine climate with wet winters and summers (CIA, 2019). Due to the location and climate, the primary natural hazard is flooding (CIA, 2019). Germany is one of the largest economies in Europe and shares borders with 9 countries; Austria, Belgium, Czech Republic, Denmark, France, Luxembourg, Netherlands, Poland, and Switzerland (CIA, 2019). The economy is primarily based on exports of machinery, chemicals and household equipment (CIA, 2019). Natural resources, like salt, uranium, nickel, copper, and coal also play a role in Germany's economy (CIA, 2019). Germany has a population of approximately 80 million as per 2018 (CIA, 2019). Additionally, similar to many developed countries, Germany faces changes to the demographic structure of its population as the fertility rates drop (CIA, 2019). These changes will see a shift in the economy as well as the infrastructure required in Germany. Climate change is not anticipated to impact Germany significantly (GFG, 2008). As a country, Germany’s policies support adaptation and resilient building infrastructure, as well as, creating avenues for research (GFG, 2008).

\section{National adaptation plan}

The German national adaptation strategy is a 73-page document that uses an integrated approach to assess risks, reduce vulnerability, improve adaptability of systems and reflects their international responsibility (GFG, 2008). The report, written by the German government, aims "to reduce vulnerability to the consequences of climate change, to maintain or improve the adaptability of natural, social and economic systems, and to take advantage of any opportunities" (GFG, 2008, 4). The plan focuses on both internal impacts and international contributions. Within Germany, the plan focuses on integrated approaches at regional levels in order to 
optimize the interactions of adaptation measures. An example provided in the plan is the integrated coastal zone management that links economic and ecological development plans to span all coastal and marine areas (GFG, 2008, 46).

For Germany and the European Union, the goal is "to limit the rise in mean global temperature to $2^{\circ} \mathrm{C}$ above the pre-industrial level, which requires a substantial reduction in greenhouse gas emissions" (GFG, 2008, 4). This adaptation plan was put forward in 2007 as a response to the United Nations call for climate change adaptation and mitigation. The plan addresses the gradual multi-factored consequences resulting from climate change and other society factors, such as population growth (GFG, 2008). The national adaptation plan acknowledges the connections with changes in international and national politics as well as implementation of new policies which could ultimately reshape the plan (GFG, 2008). The goal of incorporating the European Union has been brought to a national level through Germany's propositions of restructuring some government departments to streamline adaptation measures (GFG, 2008). For example, Germany proposes to improve health systems to meet the new forecasted changes to their natural system, in this way, the human system is adapted to fit the build environment (GFG, 2008). Additionally, this strategy acknowledges the gaps in knowledge and notes that the many uncertainties in forecasted changes will alter future impacts and possible responses (GFG, 2008).

The adaptation plan contains several sections, including climate change forecasts, consequences and actions to mitigate those consequences; their international responsibility; and the next steps required to create a fully functional adaptation plan (GFG, 2008). 


\section{Vulnerabilities}

For Germany, increasing temperatures, changes in precipitation patterns, and uncertainty of the severity of impacts are the main climate change impacts (GFG, 2008). With these changes, the German environment and society will face more frequent extreme events, continuous longterm changes to flora and fauna (such as bird species breeding), groundwater recharge problems, and impacts on heating requirements (GFG, 2008). These impacts are acknowledged in the German adaptation plan. The plan outlines vulnerabilities in the following areas: health, building sectors, water management and protection, soil, biological diversity, agriculture, forestry and forest management, fishery, energy industry, financial services industry, transport infrastructure, trade, tourism, and development planning (GFG, 2008). This plan thoroughly presents the societal impacts of climate change on the German population (GFG, 2008). The list of vulnerabilities is extensive and has listed regional vulnerabilities. For example, trends in south western Germany indicate that there is an above average temperature pattern being observed, which can result in larger impacts for agriculture and forestry industries (GFG, 2008). Overall, Germany will be less impacted by climate change than most countries. There is increasing focus on health care, such as infectious diseases, health consequences (such as asthma), and heat stress, as changes to the norm in Germany will occur with changes to temperature, precipitation, and air quality (GFG, 2008). The vulnerabilities can be addressed if there is enough time, research and innovation used to increase the systems' resilience. 


\section{Germany and Migration}

Overall, migration is mentioned 18 times in Germany's national adaptation plan under three primary topics: international responsibility, worldwide adaptation, and Germany's role in adaptation measures in developing countries (GFG, 2008, 52). In the German national adaptation plan, adaptation to the impacts of climate change "is also becoming increasingly important for cooperation on development, security and environmental policy and for migration policy" (GFG, 2008, 7). In their national adaptation plan, Germany has acknowledged migration and their international responsibility towards those affected. When developing migration policies, dialogue is from an EU perspective calling on cooperation from the entire EU and countries along migration routes (GFG, 2008). Although Germany acknowledges the possibility of climate change migration, their national adaptation plan makes an appeal to neighboring EU countries to share the burden of migration and emphasizes the need to cooperate with one another (GFG, 2008).

Germany's adaptation plan also includes that the "global migration policy dialogue should be expanded to include the aspect of future effects of climate change" (GFG, 2008, 64). By acknowledging that policy dialogue should be expanded, policies can be revised and undergo continuous development. As Germany has acknowledged that "there are gaps in our knowledge and considerable uncertainties about the details of how our climate will change in the future", migration policy must be flexible to accommodate future impacts that are currently unknown (GFG, 2008, 4). Climate change is not static. While these are positive realizations, Germany's national adaptation plan strings together a variety of buzzwords and hopes of European cooperation without detailing specific actions to be taken in the event of becoming a receiving nation of climate migrants. The vague language underpinning their international responsibility as 
a potential receiving country complies with current international obligations. With this plan, Germany has laid out how to address climate change impacts but not resultant migration. Overall, Germany's acknowledgment of climate change being a 'push' factor for migration and having addressed an international responsibility towards those migrants is crucial for recognition of climate-induced migration.

The German adaptation plan addresses their commitment and sense of responsibility to climate change adaptation in developing countries. The plan acknowledges that certain developing countries "are particularly vulnerable to adverse effect of climate change" and are to be given assistance (GFG, 2008, 51). Germany provides primarily financial support to developing countries to ensure their autonomy. For Germany, like other countries, assistance, international responsibility, and financial aid are linked. As these linkages draw on stakeholders, financial aid can come with strings of their own. However, the German national adaptation plan states that increasing the developing countries resilience will minimize Germany's long-term role. This solution offers developing countries support without undermining their autonomy and developed countries can ideally minimize outmigration.

Climate-induced migration creates polarizing discourses when discussing climate migrants. For developing countries, "the frequent representation of "drowning" Pacific islanders as the "canary in the coal-mine" especially portrays a victimizing, racialized picture, but the global South as a whole is also presented in this way when it comes to the effects of anthropogenic climate change" (Klepp, 2017, 10). In the German national adaptation plan, the autonomy of developing countries is discussed, however, there is still a portrayal of victimhood placed on these nation-states. The national adaptation plan states:

Climate change effects will have particularly serious impacts in many developing countries, especially in Africa and the small island states. The people of these developing countries are 
the main victims of climate change, which has so far been largely caused by the industrialised countries. (GFG, 2008, 52)

Developing countries, like the Maldives, refute the "drowning" victim label, as it forced a perspective of hopeless on them as well as an acceptance of future reliance upon other countries. In the case of developing nations becoming victims of climate change, the tone of victimhood is hopeful as developing countries as well as climate-induced migrants should be treated with dignity and support. Germany identifies a sense of responsibility towards developing countries as they recognize that climate change is largely caused by industrialized countries (GFG, 2008). In this recognition, the national adaptation plan provides financial mechanisms for support that add to the hopeful tone. Other countries, like the US, back out of their international responsibilities due to political pressures and national politics, but it is important to recognize that there are some developed countries who are helping with poverty alleviation and laying the foundation for climate policy.

Germany's national adaptation plan also discusses regional migration and "touristical migration":

Around the world, climate-induced adverse effects on existing economic and environmental framework conditions are already affecting some migratory movements on a regional and supra- regional scale. (GFG, 2008, 53)

This emphasizes that Germany acknowledges regional migration while providing a vague scale at which this migration would occur. Despite the vagueness, addressing regional migration creates a pathway for future discussions of environmental displacement. In the migration context, Germany also mentions "touristical migration" wherein warmer weather in Germany can potentially benefit the tourism industry (GFG, 2008, 39). The addition of the movement of flora and fauna, regional migration, and "touristical migration" in Germany's national adaptation plan demonstrate that this plan encompasses many other sectors, such as the tourism industry, in 
which benefits can be gained for Germany. This indicates that Germany is not afraid of mentioning migration, but does not explicitly use the word refugee.

According to the United Nations, there are many reasons for migration:

"Some people move in search of labour or economic opportunities, to join family, or to study. Others move to escape conflict, persecution, terrorism, or human rights violations. Still others move in response to the adverse effects of climate change, natural disasters, or other environmental factors" (United Nations, 2018).

While escaping conflict, persecution, terrorism, or human rights violations are addressed in the convention refugee definition, migration as a result of climate change is still not included in international law. As earlier explained, some countries allow temporary measures for natural, or other environmental disasters, as seen in Canada and the US in response to the 2010 Haitian earthquake. While this allows for migration pathways to be created for fast onset events, some countries, like Germany, want to begin by addressing impacts in the countries of origin (GFG, 2008, 53):

From a migration policy point of view, the German contribution could consist primarily in maintaining or strengthening existing development policy approaches and incentives to combat the reasons for migration, and to align them with foreseeable future impacts of climate change in the countries of origin.

This quote highlights that Germany wants to enhance their current policies while trying to mitigate the reasons people would want to migrate due to climatic change (GFG, 2008). The national adaptation plan does identify climate-induced migration, however, only formally and in relation to stemming migration not accepting migrants. This strategy focuses on adaptation techniques and draws on an aspect of their international responsibility. In this adaptation plan, Germany does not shy away from their international responsibility for migration. For Germany combating the reasons for migration decreases the likelihood that Germany will become a 
receiving country and by doing development work in developing countries, might diminish the magnitude of estimated migration.

For Germany, estimated migration can be mitigated in the country of origin, but there is the acknowledgement that climate change reinforces the push effects of migration (GFG, 2008, 53). While this plan does not talk about people migrating because of loss of land, it focuses on other factors that would lead to migration along already established migration routes (GFG, 2008, 53).

Resulting persistent deterioration in living conditions could lead to social tensions and destabilisation of society, and to political or possibly religious radicalisation of the population in the countries of origin. This could result in an intensification of the economic, political, religious or conflict-related motives and reasons for flight, and in increased migration. This could in particular affect the countries along the existing migration routes to the European Union and adjacent regions. Studies of the connections between climate change and migration are in progress. Many of these potential cause-and-effect chains depend on timely adaptation efforts and effective combating of poverty or reasons for flight by the countries of origin themselves. (GFG, 2008, 53)

The push and pull factors identified in the quote above, are all factors that are currently considered in migration decisions. In this quote, Germany has underlined that societal factors and tensions as well as the destabilizations of societies have an undertone of potential security concerns for Germany. Additionally, 'religious radicalisation' and 'intensification of [...] conflict-related motives' add a national security risk perspective. The focus on social issues caused by climate change impacts presents a complex issue for developed countries, who cannot make decisions for developing nations, but simultaneously, would like to prevent any 'reasons for flight' (GFG, 2008).

From a national security perspective, Germany has taken measures for containing security risks in an adaptation context (GFG, 2008). National security does not stop at Germany's border and this aspect of their national adaptation plan emphasizes that security is a top concern with international discussions occurring at the United Nations, and at the European Union, as well as 
at a national level with the 2007 publication of "World in Transition - Climate Change as a Security Risk", also referenced in their adaptation plan (GFG, 2008).

The 2007 publication details both human security concerns as well as national and international concerns (Schubert et al., 2007). The report provides two perspectives: one of destabilization and violence and the other of international cooperation (Schubert et al., 2007). Both perspectives are seen in the German adaptation plan. Destabilization and violence are addressed as security threats of migration and are considered risks that "relate largely to conflict constellations and to potential new migrations in fragile states or states with weak governmental structures that are particularly affected by impacts of climate change such as increasing water shortage, food shortages and natural disasters" (GFG, 2008, 51). Germany has the ability to increase the resiliency of some states through development assistance and have planned to do so. These plans can help maintain water and food availability and offer aid when natural disasters occur.

The second perspective of cooperation is seen in the focus on international aid and suggestions made by the "World in Transition - Climate Change as a Security Risk" report (GFG, 2008). The ambitious international cooperation suggestion is to put into operation a global climate policy over the next 10-15 years (Schubert et al., 2007, 1). It has been 12 years since this report was written in 2007 , and no global climate policy have been adhered to on international platform. Additionally, other policies, like the Kyoto Protocol, are not being adhered to by all ratifying countries (UNFCCC, 2019). This report refers to six threats to international stability and security, with the fifth one being "triggering and intensification of migration" citing the "polluter pays" principle wherein industrialized countries have responsibilities as the main polluters (Schubert et al., 2007). The "polluter pays" principle and sense of responsibility 
towards developing countries is apparent throughout Germany's adaptation plan (GFG, 2008).

The German perspective on climate-induced migration is complex but maintains firm stances on developmental aid, and national security. 


\begin{abstract}
ANALYSIS
An analysis of both adaptation plans can draw attention to the different techniques and focuses of developed versus developing nations. This comparison is limited to two national adaptation plans but highlights mechanisms that can be used to address adaptation barriers, and sheds light on resilience-increasing techniques.
\end{abstract}

\title{
Aims of both plans
}

The aims of Germany's and the Maldives' adaptation plans are different. For Germany, "the aim of the Adaptation Strategy is to reduce vulnerability to the consequences of climate change, to maintain or improve the adaptability of natural, social and economic systems, and to take advantage of any opportunities” (GFG, 2008, 4). Their plan also reflects Germany’s international responsibility, making it clear that Germany will offer support to developing nations and that there is an inherent responsibility for those who created the problem to address it (GFG, 2008). For the Maldives, "the goal of the NAPA is to present a coherent framework to climate change adaptation that enhances the resilience of the natural, human, and social systems and ensures their sustainability in the face of predicted climate hazards" (MoEEW, 2007, 3). This framework focuses on building resilience into their social systems. Overall, both plans are thorough and highlight specific needs within their own borders.

Germany focuses more on stakeholder relations within the country whereas the Maldives appears to be a call to action for its citizens as well as the international community. At the same time, Germany addresses its international responsibility towards climate change and climate migrants as they share the responsibility in creating this issue. Given the unique situations in both countries, the Maldives' call to action and Germany's focus on stakeholder relations are logical. The Maldives highlights the fragility of the physical state of their islands, while 
Germany comments on the ability to take "advantage of any opportunities". The Maldivian adaptation plan only mentions refugees or migrants once, likely as they will not be acting as a receiving country. By contrast, Germany addresses migration and migration routes, as they will likely become a receiving country unsure of the potential number of migrants they will receive.

The Maldives adaptation plan is a call to action, as seen in the following quote:

I call upon all Government agencies, our international development partners and friends to extend their full cooperation to us to make this adaptation programme a success. (MoEEW, 2007, iv)

Germany's plan is more focused on building relationships with stakeholders as not only governments and administrative authorities are affected by national policy changes (GFG, 2008, 6). The Maldives relies on the international community's sense of responsibility whereas Germany mobilises their resources in response. Although there is no direct link between the Maldives and Germany, they are indirectly linked, like all developing and developed countries, by cooperative agreements and normative commitments in the international arena. As such, national adaptation plans can be created from two different perspectives: one from the country of origin and one from the receiving country. For the country of origin, a perspective of imposed victimhood can also frame the national adaptation plans, whether self-imposed or ascribed from developed nations.

\section{Has anything actually been done?}

As Germany promised in their adaptation plan, Germany published an action plan in 2011. The action plan provides more details on how Germany will deal with anthropogenic climate change impacts. Germany has begun to meet their international responsibilities by including adaptation within the international climate regime, "by adhering to international and European relations and cooperation, and in the field of research and development" (Germany 
Federal Cabinet, 2011, 35). Germany has developed sustainability partners and have contributed to research in climate change fields. Additionally, after the action plan, large groups of refugees came across the Mediterranean and Germany reacted, welcoming and settling 1.2 million refugees between 2015 and 2016 into Germany Spiegel Staff (2017). While environmental factors were not attributed to be the primary driving force behind this migration movement, the reaction, resettlement, and 'welcoming' discourse provides hope for future migration crises.

For the Maldives, discussions on an international platform about climate change adaptation, mitigation, and country commitments to reduce their greenhouse gas emissions have created awareness regarding the Maldives' potential plight (Warne, 2015). Seawalls, breakwaters, harbors, and artificial beaches have been designed and implemented to mitigated future impacts to the islands (Warne, 2015). These physical barriers reinforce the "stay and fight" mentality that can be seen in the Republic of Maldives national adaptation plan (Warne, 2015).

\section{Is there an opportunity to better link displacement and climate in future NAPs?}

While future national adaptation plans can better link displacement and climate change, they are unlikely to do so as countries can create migration policies without $\mathrm{UN}$ consultation or support. The conversation surrounding climate change and the connections to migration are beginning to happen more frequently as the 'point of no return' is in 2020 (UN, 2018a). The 'point of no return' is when the global ecosystem is unable to maintain our current equilibrium due to the forces acting on the system (NRC, 2011). The current research addressing environmental displacement and environmental migration examines actions taken and how improvements can be implemented (UN, 2018a). An example of environmental displacement, though not classified as a climate hazard, is presented by Omeziri \& Gore (2014) as they 
examined temporary protected status for those displaced by the 2010 Haitian earthquake. These temporary measures can be included in future national adaptation plans as the forecasts point to increased frequency of extreme events that would cause displacement (IOM, 2009).

While temporary measures can be included in future national adaptation plans, climateinduced migration can be addressed outside of NAPs. Similar to Canada's temporary protected status, New Zealand has proposed a special humanitarian visa to allow those affected by climate change a migration path (Taylor, 2017). While this visa has yet to be implemented, policy is being considered at a national level to fill the void left by the UN convention refugee definition in which environmental reasons are finally addressed (Taylor, 2017). While these temporary measures are not included in national adaptation plans, they should become the norm for developed countries. For Germany and the European Union, mitigating climate change impacts and reducing the pressures of migration is the preferred pathway to deal with climate change (Lacy, 2012). However, an avenue that can be explored within the EU are bilateral partnerships allowing temporary migration pathways to form (Lacy, 2012). Bilateral partnerships, such as the Temporary and Circular Labour Migration (TCLM) between Colombia and Spain relocates people during natural disasters allowing temporary migration pathways to be formed (Lacy, 2012). The aforementioned examples suggest that policy is being developed to address climateinduced migration but on an ad hoc basis.

For the national adaptation plans, the details within the German national adaptation plan surpass the Maldivian adaptation plan based on the amount of environmental impacts and divisions of the environment considered. For example, Germany considers the biome of the soil and its potential change over time. The Maldives focuses less on details of environment, and more on the social sector of climate change. The adaptation plans in the Maldives points to the 
lack of current infrastructure and the need to create stable infrastructure to begin. It reinforces just how different the starting points for both nations are. The starting points of these nations are unlikely to change drastically prior to environmental migration pressures and are essential to consider when creating a national adaptation plan. For both nation states, migration is not the focal point. For Germany, climate-induced migration is a security concern while the Maldives does not want to address migration as a form of adaptation. Contextually, for the Maldives, migration would be considered maladaptation and until their land is uninhabitable, not a viable solution. Overall, these plans do not focus on migration but the plans can both, or could both in future, make a clearer link between displacement and climate change. 


\section{CONCLUSION}

Anthropogenic climate change will affect developed and developing countries in different ways. For developing countries, there are concerns around the lack of available resources and infrastructure to address large-scale climate change impacts (Eisenack and Stecker, 2011). Additionally, some developing countries, like SIDS, will face climate change impacts that could force out-migration (Wijaya, 2014). These locations, like the Republic of Maldives, would become reliant on other nation states to accept their citizens (Eisenack and Stecker, 2011). In contrast, developed nations, like Germany, are forecasted to be less severely impacted by climate change impacts and have a more robust social, economic, and geopolitical infrastructure. Developed nations also have a higher capacity for adaptation because of the wealth of resources and current infrastructure in place (Cameron, 2017).

A common theme between the national adaptation plans presented by both the Maldives and Germany is that neither country wants climate change adaptation to result in migration. For developed nations, it comes with security risks and a high price tag. For small island developing states, it means changing their lifestyles and their lives. There is a more hopeful tone in Germany's adaptation plan as they see some benefits to take advantage of, while the Maldives presents a positive outlook there are urgent undertones due to the call to action.

Overall, the role of adaptation plans should not be downplayed and can play a significant role in articulating the connection between climate change and migration. While the environmentmigration nexus is still being considered for the Convention Refugee definition, there is nothing to prevent countries from developing migration policies for those fleeing environmental impacts. Adaptation plans can act as the connection between environment, and migration as well as create a platform through which countries can address their international responsibilities. The outlook 
for migration plans using environmental reasons as grounds for migration have been increasingly focused on and discussed in various countries. Climate-induced migration is a reason for alarm, but with the proper plans in place, can be addressed to mitigate harmful impacts. 


\section{REFERENCES}

Adger, N., Dessai, S., Goulden, M., Hulme, M., Lorenzoni, I., Nelson, D., Naess, L., Wolf, J., Wreford, A. (2009). Are there social limits to adaptation to climate change? Climatic Change. 93: 335-354.

Advisory Group on Climate Change and Human Mobility. (2015). Human Mobility in the Context of Climate Change - Elements for the UNFCCC Paris Agreement 2015. United Nations Framework Convention on Climate Change. Retrieved from: http://www.unhcr.org/5550ab359.pdf [Accessed on August 13, 2018].

Baldwin, A., Fornale, E. (2017). Adaptive migration: pluralising the debate on climate change and migration. The Geographical Journal. 183 (4): 322-328.

Baldwin, A., Methmann, C., Rothe, D. (2014). Securitizing 'climate refugees': the futurology of climate-induced migration. Critical Studies on Security. 2 (2): 121-130.

Bates, D. (2002). Environmental refugees? Classifying human migrations caused by environmental change. Population and Environment. 23 (5): 465-477.

Becklumb, P. (2013). Climate Change and Forced Migration: Canada's Role. Industry, Infrastructure and Resource Division: Parliamentary Information and Research Service. Publication No. 2010-04-E.

Bettini, G., Nash, S., Giol, G. (2016). One step forward, two steps back? The fading contours of (in)justice in competing discourses on climate migration. The Geographical Journal. DOI: $10.1111 /$ geoj. 12192

Biesbroek, R., Swart, R., Carter, T., Cowan, C., Henrichs, T., Mela, H., Morecroft, M., Rey, D. (2010). Europe adapts to climate change: Comparing national adaptation strategies. Global Environmental Change. 20 (3):440-450.

Boano, C., Zetter, R., Morris, T. (2008). Environmentally displaced people: Understanding the linkaged between environmental change, livelihoods and forced migration. Refugee Studies Center. Oxford Department of International Development. University of Oxford.

Brown, K., Kerry Turner, R., Hammed, H., Bateman, I. (1997). Environmental carrying capacity and tourism development in the Maldives and Nepal. Environmental Conservation. 24(4):316-325.

Bruno, G., Palombino, F., Rossi, V. (2017). Migration and the environment: some reflections on current legal issues and possible ways forward. CNR Edizioni (eds,) ISBN 978888080 2778.

Cameron, M. (2017). Climate change, internal migration, and the future spatial distribution of population: a case study of New Zealand. Population and Environment. 39(3):239-260. 
Castles, S. (2013). The forces driving global migration. Journal of Intercultural Studies. 34(2): 122-140.

Central Intelligence Agency [CIA]. (2019). Germany: World Factbook. Retrieved from: https://www.cia.gov/library/publications/the-world-factbook/geos/gm.html [Accessed on January 17, 2019].

Compton, B. (2014). The rising tide of environmental migrants: Our national responsibilities. Colorado National Resources, Energy and Environmental Law Review. 25 (2): 357-386.

Corrao, I. (2018). EU-Turkey statement and action plan. European Parliament. Retrieved from: http://www.europarl.europa.eu/legislative-train/theme-towards-a-new-policy-onmigration/file-eu-turkey-statement-action-plan [Accessed on November 18, 2018].

Creswell, J. (2013). Qualitative Inquiry and Research Design: Choosing Among Five Approaches. Thousand Oaks, CA: Sage.

Eisenack, K., Stecker, R. (2011). A framework for analyzing climate change adaptations as actions. Mitigation and Adaptation Strategies for Global Change. 17(3):243-260.

European Parliament [EP]. (2011). "Climate refugees" Legal and policy responses to environmentally induced migration. European Parliament's Committee on Civil Liberties. Retrieved from: http://www.europarl.europa.eu/thinktank/en/document.html?reference=IPOLLIBE_ET\%282011\%29462422 [Accessed on May 25, 2018].

Felgentreff, C., Pott, A. (2016). Climatic turn in migration studies? Geographical perspectives on the relationship between climate and migration. Journal of the Geographical Society of Berlin. 147(2): 73-80.

Felli, R. (2012). Managing climate insecurity by ensuring continuous capital accumulation: 'Climate refugees' and 'Climate migrants'. New Political Economy. 13(3): 337-363.

German Federal Cabinet. (2011). Adaptation Action Plan of the German Strategy for Adaptation to Climate Change. German Federal Cabinet. Retrieved from: https://www.bmu.de/fileadmin/bmuimport/files/pdfs/allgemein/application/pdf/aktionsplan_anpassung_klimawandel_en_bf.p df [Accessed on January 12 2019].

Girvan, N. (2007). Power Imbalances and Development Knowledge. Southern Perspectives on Reform of the International Development Architecture. The North-South Institute. Retrieved from: https://www.oecd.org/site/oecdgfd/39447872.pdf 
Hamilton, L., Saito, K., Loring, P., Lammers, R., Huntington, H. (2016). Climigration?

Population and climate change in Arctic Alaska. Population and Environment. 38(2):115133.

Holidays and Host. (2018). Maldives: Luxury Vacations. Retrieved from:

https://holidaysandhost.com/maldives/ [Accessed on December 2, 2018].

Hollifield, J., Salehyan, I. (2015). Environmental Refugees. Wilson Center. Retrieved from: https://www.wilsoncenter.org/article/environmental-refugees [Accessed on September 24, 2018].

Homer-Dixon, T. (1999). Environment, Scarcity, and Violence. Princeton, NJ: Princeton University Press.

Huntjens, P., Nachbar, K. (2015). Climate change as a threat multiplier for human disaster and conflict. The Hague Institute for Global Justice. Working Paper 9.

German Federal Government [GFG]. (2008). German Strategy for Adaptation to Climate Change. Retrieved from: https://www.preventionweb.net/files/27772_dasgesamtenbf163.pdf [Accessed on April 30, 2018].

Grbich, C. (2013). Qualitative Data Analysis: An Introduction. Los Angeles, CA: SAGE.

International Organization for Migration [IOM]. (2008). Migration and Climate Change. No.31. International Organization for Migration.

International Organization for Migration [IOM]. (2009). Migration, Environment and Climate Change: Assessing the Evidence. International Organization for Migration.

International Organization for Migration [IOM]. (2011). International Migration Law N 25 Glossary on Migration. Vol. 25. ISSN: 1813-227825.

International Organization for Migration [IOM]. (2016). How can migration support adaptation? Different options to test the migration-adaptation nexus. Migration, Environment and Climate Change: Working Paper Series. Retrieved from: https://publications.iom.int/system/files/working_paper_series_1.pdf [Accessed on January 18, 2019].

Intergovernmental Panel on Climate Change [IPCC]. (2007). Climate change 2007: Synthesis Report. Retrieved from: https://www.ipcc.ch/pdf/assessmentreport/ar4/syr/ar4_syr_full_report.pdf [Accessed on April 30, 2018].

Intergovernmental Panel on Climate Change [IPCC]. (2007a). Climate change 2007: Working group II: Impacts, Adaptation and Vulnerability. Retrieved from: https://www.ipcc.ch/publications_and_data/ar4/wg2/en/ch19s19-1-2.html [Accessed on June 9, 2018]. 
Khan, T., Quadir, D., Murty, T., Kabir, A., Aktar, F., Sarker, M. (2010). Relative sea level changes in Maldives and vulnerability of land due to abnormal coastal inundation. Marine Geodesy. 25(1-2):133-143.

Klepp, S. (2017). Climate change and migration. Oxford Research Encyclopedia of Climate Science. DOI: 10.1093/acrefore/9780190228620.013.42

Kumar, C. (2014). Climate Change in South Asia: A Framework of Sustainable Development and Human Security. Journal of Environment Pollution and Human Health. 2(5):100109.

Lacy, S. (2012). Climate change and migration: possible roles for Germany Development Cooperation. Discussion Paper. Deutsche Gesellschaft fur Internationale Zusammenarbeit (GIZ) GmbH. Retrieved from: https://www.cimonline.de/static/media/giz2012-en-climate-and-migration.pdf [Accessed on Jan 19 2019].

LDC Expert Group. (2012). National adaptation plans: technical guidelines for the national adaptation plan process. United Nations Framework Convention on Climate Change. Retrieved from https://unfccc.int/files/adaptation/cancun_adaptation_framework/application/pdf/naptech guidelines_eng_high_res.pdf [Accessed on January 12 2019].

Locke, J. (2009). Climate change-induced migration in the Pacific Region: sudden crisis and long-term developments. The Geographical Journal. 175(3): 171-180.

Lonergan, S., Parnwell, M. (1998). Environmental degradation and population movement. Environment and Security. 3(1): 1-26.

Magnan, A., Ribera, T., Treyer, S. (2015). National adaptation is also a global concern. Working Papers. No.4/15, IDDRI, Paris, France.

Maiani, F. (2010). The concept of "persecution" in refugee law: indeterminacy, contextsensitivity, and the quest for a principled approach. Les Dossiers du Grihl, De la persécution. Retrieved from: http://journals.openedition.org/dossiersgrihl/3896 [Accessed on August 22, 2018].

Mainwaring, C. (2016). Migrant agency: Negotiating borders and migration controls. Migration studies. 4(3): 289-308.

Maldives. (2018). Its all about Maldives. Retrieved from: https://www.maldives.com/aboutmaldives/ [Accessed on October 4, 2018]. 
Manasfi,N., Sepp, S. (2013). Putting national adaptation planning into practice. Federal Ministry for Economic Cooperation and Development. Retrieved from:

https://www.adaptationcommunity.net/?wpfb_dl=151 [Accessed on January 31, 2019].

Mayer, B. (2012). 'Environmental Refugees?': A critical perspective on the normative discourse. Available at SSRN:http://dx.doi.org/10.2139/ssrn.2111825

Methmann, C., Oels, A. (2015). From 'fearing' to 'empowering' climate refugees: Governing climate-induced migration in the name of resilience. Security Dialogue. 46(1):51-68.

McMichael, A. (2013). Global Health: Globalization, Climate Change, and Human Health. The New England Journal of Medicine. 368(14): 1335-1343.

McNut, M. (2013). Climate change impacts. Science. 341 (6145). 435.

Merriam-Webster. (2019). Anthropogenic. Retrieved from: https://www.merriamwebster.com/dictionary/anthropogenic [Accessed on April 14, 2019].

Ministry of Environment, Energy, and Water [MoEEW]. (2007). National Adaptation Program of Action: Republic of Maldives. Retrieved from: https://unfccc.int/resource/docs/napa/mdv01.pdf [Accessed on April 12, 2018].

Mimura, N., Pulwarty, D., Elshinnawy, I., Redsteer, M., Huang, H., Nkem, J., Sanchez, R. (2014). Adaptation planning and implementation. Climate change 2014: Impacts, Adaptations, and vulnerability. Part A: Global and Sectoral Aspects, Contribution of Working Group II to the Fifth Assessment Report of the Intergovernmental Panel on Climate Change. Cambridge, United Kingdom and New Yoek, NY. USA. 869-898.

Muradian, R., Rival, L. (2012). Between markets and hierarchies: The challenge of governing ecosystem services. Ecosystem Services.1(1):93-100.

National Research Council [NRC]. (2011). Understanding Earth's deep past: Lessons for our climate future. Washington, DC: The National Academies Press. https://doi.org/10.17226/13111.

Nightingale, A. (2017). Power and politics in climate change adaptation efforts: Struggles over authority and recognition in the context of political instability. Geoforum. 84: 11-20

Nesheim, E. (2009). Conceptualizing climate change migration: A literature review and analysis of the state of the field and its implications. Tufts Digital Library. Retrieved from: http://hdl.handle.net/10427/55668 [Accessed on April 30, 2018].

Newland, K. (2011). Climate change and migration dynamics. Washington, DC: Migration Policy Institute. 
O'Brien, K., Leichenko, R. (2000). Double exposure: assessing the impacts of climate change within the context of economic globalization. Global Environmental Change. 10: 221232.

O'Malley, P. (1992). Risk, power and crime prevention. Economy and Society. 21(3):252-275.

Omeziri, E., Gore, C. (2014). Temporary measures: Canadian refugee policy and environmental migration. Refugee. 29 (2): 43-53.

Pierre-Neilson, S., Battig, M., Imboden, D. (2008). Exploring the link between climate change and migration. Climatic Change. 91:375-393.

Piguet, E. (2010). Linking climate change, environmental degradation, and migration: a methodological overview. JOhn Wiley and Sons, Ltd. 1: 519-524. DOI: 10.1002/wcc.54

Raleigh, C., Jordan, L., Salehyan, I. (2008). Assessing the impact of climate change on migration and conflict. The Social Development Department, The World Bank Group. Washington, DC. 5-6, March 2008.

Scheffran, J., Marmer, E., Sow, P. (2012). Migration as a contribution to resilience and innovation in climate adaptation: Social networks and co-development in Northwest Africa. Applied Geography. 33:119-127.

Schubert, R., Schellnhuber, H., Buchmann, N., Epiney, A., GrieBhammer, R., Kulessa, M., Messner, D., Rahmstorf, S., Schmid, J. (2007). Climate Change as a Security Risk. German Advisory Council on Global Change (WBGU). London, UK.

Skeldon, R. (2017). Internal migration, internal migration, mobility and urbanization: Towards more integration approaches. United Nations Expert Group Meeting on Sustainable cities, Human mobility and International MIgration. Population Division. Department of Economic and Social Affairs. United Nations Secretariat. Retrieved from: http://www.un.org/en/development/desa/population/events/pdf/expert/27/papers/II/paperSkeldon-final.pdf [Accessed on September 14, 2018].

Soderblom, J. (2008). Climate Change: National and regional security threat multiplier for Australia. Security Solutions. 52: 58-58.

Spiegel Staff. (2017). Germany's ongoing project to welcome its refugees. Spiegel Online. Retrieved from: http://www.spiegel.de/international/germany/integrating-refugees-ingermany-an-update-a-1147053.html [Accessed on January 12 2019].

Stapleton, S., Nadin, R., Watson, C., Kellett, J. (2017). Climate change, migration and displacement. United Nations Development Program. Retrieved from: https://www.odi.org/sites/odi.org.uk/files/resource-documents/11874.pdf [Accessed on May 4, 2018]. 
Stone, D. (2018). Refugees then and now: memory, history and politics in the long twentieth century: an introduction. Patterns of Prejudice. 52(2-3):101-106.

Tacoli, C. (2009). Crisis or adaptation? Migration and climate change in a context of high mobility. Environment and Urbanization. 2(2):513-525.

Taylor, L. (2017). New Zealand considers visa for climate 'refugees' from Pacific islands. Retrieved from: https://www.reuters.com/article/us-newzealand-climatechange-visa/newzealand-considers-visa-for-climate-refugees-from-pacific-islands-idUSKBN1DH1JB [Accessed on December 4, 2018].

Thomas, A., Benjamin, L. (2018). Policies and mechanisms to address climate-induced migration and displacement in Pacific and Caribbean small island developing states. International Journal of Climate Change Strategies and Management. 10 (1): 86104.

Till, C., Haverkamp, J., White, D., Bhaduri, B. (2016). Understanding climate-induced migration through computational modeling: A critical overview with guidance for future effects. Journal of Defense Modeling and Simulation: Applications, Methodology, Technology. DOI: $10.1177 / 1548512916679038$.

Trevors, J. (2011). Human Addictions: Oil, Conflicts, and Super Consumerism. Water, Air, \& Soil Pollution. 217(1-4):1-2.

Trombetta, M. (2014). Linking climate-induced migration and security within the EU: insights from the securitization debate. Climate Change and migration: from geopolitics to biopolitics. 2(2): 131-147.

Ragheboom, H. (2017). The international legal status and protection of environmentallydisplaced persons: A European perspective. International Refugee Law Series. Brill.

Rempell, S. (2013). Defining Persecution. Utah Law Review. 2013 (1). Retrieved from: http://dx.doi.org/10.2139/ssrn.1941006 [Accessed on August 22, 2018].

Republic of Maldives [RM]. (2006). National Adaptation Program of Action: Republic of Maldives. Retrieved from: https://unfccc.int/resource/docs/napa/mdv01.pdf [Accessed on April 30, 2018].

Roberts, E., Andrei, S. (2015). The rising tide: migration as a response to loss and damage from sea level rise in vulnerable communities. International Journal Global Warming. $8(2): 258-273$.

United Nations (2017). International migration report. United Nations. Department of Economic and Social Affairs, Population Division. Retrieved from:

http://www.un.org/en/development/desa/population/migration/publications/migrationrepo rt/docs/MigrationReport2017_Highlights.pdf [Accessed on September 14, 2018]. 
United Nations (2018). Migration. United Nations. Retrieved from: http://www.un.org/en/sections/issues-depth/migration/index.html [Accessed on December 12, 2018].

United Nations (2018a). World 'Nearing critical point of no return' on climate change, delegate warns, as Second Committee debates sustainable development. Retrieved from: https://www.un.org/press/en/2018/gaef3500.doc.htm [Accessed on January 19 2019].

United Nations Framework Convention on Climate Change [UNFCCC]. (2011). Annex: Initial guidelines for the formulation of national adaptation plans. Retrieved from: http://unfccc.int/files/adaptation/cancun_adaptation_framework/national_adaptation_plan s/application/pdf/nap_initial_guidelines_annex_to_decision_5cp17_eng.pdf [Accessed on September 19, 2018].

United Nations Framework Convention on Climate Change [UNFCCC]. (2018). Glossary of key terms. UNFCCC NAP Central. Retrieved from: http://www4.unfccc.int/nap/Pages/glossary.aspx. [Accessed on August 20, 2018].

United Nations Framework Convention on Climate Change [UNFCC1]. (2018). National Adaptation Plan. Retrieved from: https://unfccc.int/topics/adaptation-andresilience/workstreams/national-adaptation-plans [Accessed on September 18, 2018].

United Nations Framework Convention on Climate Change [UNFCCC2]. (2018). Overview National Adaptation Plans. Retrieved from: https://unfccc.int/topics/resilience/workstreams/national-adaptation-plans/overview [Accessed on September 24, 2018].

United Nations Framework Convention on Climate Change [UNFCCC]. (2019). Kyoto Protocol - Targets for the first commitment period. Retrieved from: https://unfccc.int/process/thekyoto-protocol [Accessed on January 27, 2019].

United Nations High Commissioner for Refugees [UNHCR]. (2017). Convention and protocol relating to the status of refugees. Retrieved from:_http://www.unhcr.org/3b66c2aa10.pdf [Accessed on May 9, 2011].

UN Office for the Coordination of Humanitarian Affairs [OCHA]. Policy Development and Studies Branch. (2011). OCHA and slow-onset emergencies. OCHA Occasional Policy Briefing Series. No. 6.

UN Water. (2014). Integrated Water Resources Management (IWRM). Retrieved from: http://www.un.org/waterforlifedecade/iwrm.shtml [Accessed on January 18, 2019].

Vincent, K. (2004). Creating an index of social vulnerability to climate change for Africa. Tyndall Center Working Paper No. 56. University of East Anglia. 
Verhelst, A. (2017). Climate change induced migration: towards a righteous approach? University of Antwerp. Retrieved from: https://www.scriptiebank.be/sites/default/files/thesis/201709/Thesis $\% 20$ climate $\% 20$ change $\% 20$ induced $\% 20$ migration $\% 20$ Anne $\% 20$ Verhelst.pdf [Accessed on September 14, 2018].

Waldinger, M. (2015). The effects of climate change on internal and international migration: implications for developing countries. Grantham Research Institute on Climate Change and the Environment, London School of Economics and Political Science.

Waldinger, M., Fankhauser, S. (2015). Climate change and migration in developing countries: evidence and implications for PRISE countries. Policy Paper. ESRC Centre for Climate Change Economics and Policy. Grantham Research Institute on Climate Change and the Environment. Retrieved from: http://eprints.lse.ac.uk/64526/1/Climate-change-andmigration-in-developing-countries_final.pdf [Accessed on August 20, 2018].

Warne, K. (2015). Will pacific island nations disappear as seas rise? Maybe not. National Geographic. Retrieved from: https://news.nationalgeographic.com/2015/02/150213tuvalu-sopoaga-kench-kiribati-maldives-cyclone-marshall-islands/ [Accessed on September 16, 2018].

Warrick, O. (2011). Local voices, local choices? Vulnerability to climate change and community-based adaptation in rural vanuatu. Research commons at the University of Waikato. Retrieved from: https://core.ac.uk/download/pdf/129933241.pdf [Accessed on September 13, 2018].

Watkiss, P. Cimato, F. (2016). The economics of adaptation and climate-resilient development: lessons from projects for key adaptation challenges. Centre for Climate Change Economics and Policy. Working Paper No.265. Grantham Research Institute on CLimate Change and the Environment.

Wijaya, A. (2014). Climate change, global warming and global inequity in developed and developing countries (Analytical perspective, issue, problem and solution). IOP Conf. Series: Earth and Environmental Science. DOI: 10.1088/1755-1315/19/1/012008.

Winter-Ebmer, R. (1994). Motivation for migration and economic success. Journal of Economic Psychology. 15: 269-284.

Yamamoto, L., Serraglio, D., Cavedon-Capdeville. (2018). Human mobility in the context of climate change and disasters: a South American approach. International Journal of Climate Change Strategies and Management. 10(1): 65-85. 